Original Article

\title{
Pengaruh Penggunaan Vidio Ilustrasi Family Planning Terhadap Pengetahuan Akseptor KB Sebagai Upaya Pencegahan Baby Boom Di Masa Pandemi Covid-19
}

\author{
The Effect of Using Family Planning Illustration Videos on Knowledge of Family \\ Planning Acceptors as an Effort to Prevent Baby Booms during the Covid -19 Pandemic
}

\author{
Rahayu Eryanti. K*1, Nurqalbi Sampara ${ }^{1}$, Jumrah Sudirman ${ }^{1}$ \\ ${ }^{1}$ Program Studi Pendidikan Profesi Bidan, Fakultas Keperawatan \& Kebidanan, Universitas \\ Megarezky, Indonesia \\ (*rahayueryanti@gmail.com)
}

\begin{abstract}
ABSTRAK
Pelayanan kesehatan salah satunya pelayanan keluarga berencana di fasilitas kesehatan juga terdampak Covid-19, dikhawatirkan bahwa akseptor KB kemungkinan khawatir untuk datang ke fasilitas kesehatan sehingga timbul risiko putus-pakai pemakaian kontrasepsi. Vidio edukasi berbasis ilustrasi menjadi salah satu metode yang dapat membantu mencegah ledakan penduduk selama pandemi. Penelitian ini bertujuan untuk menilai pengaruh penggunaan vidio ilustrasi family planning terhadap pengetahuan akseptor KB dalam penggunaan kontrasepsi selama masa pandemi Covid-19. Jenis penelitian ini adalah penelitian kuantitatif dengan metode penelitian Quasi Eksperiment dengan pendekatan pretest-posttest with control group. Pada penelitian ini terbagi menjadi dua kelompok yaitu intervensi dengan pemberian edukasi dengan vidio ilustrasi dan kontrol menggunakan edukasi konvensional atau menggunakan lembar balik. Hasil penelitian yaitu akseptor KB yang diberikan edukasi vidio ilustrasi family planning memiliki pengetahuan dengan nilai rata-rata \pm SD yaitu 58,89 $\pm 15,86$, sedangkan pada kelompok kontrol didapatkan nilai rata-rata \pm SD yaitu $45,47 \pm 4,31$. Hasil uji $t$ independent menunjukkan ada pengaruh video ilustrasi family planning terhadap pengetahuan akseptor KB di Puskesmas Wilayah Kota Makassar $(\mathrm{P}=0,012)$. Video ilustrasi family planning efektif terhadap pengetahuan akseptor KB di Puskesmas Wilayah Kota Makassar khususnya di masa pandemi covid-19 saat ini.
\end{abstract}

Kata kunci : Baby boom, pengetahuan, video ilustrasi, pandemic covid-19,

\section{ABSTRACT}

Health services, One of them is family planning services in health facilities which are also affected by Covid-19, it is feared that family planning acceptors may be worried about coming to health facilities, so there is a risk of using contraceptives. Illustration-based educational videos are one method that can help prevent population explosions during a pandemic. This study aims to assess the effect of the use of illustrated family planning videos on the knowledge of family planning acceptors in the use of contraception during the Covid-19 pandemic. This type of research is quantitative research with Quasi Experiment research method with pretest-posttest approach with control group. In this study, it was divided into two groups, namely intervention by providing education with illustrations and conventional educational control or using flipcharts. Results: Family planning acceptors who were given family planning illustration video education had knowledge with an average score of 58, 89, while in the conventional treatment group, the score was 45,47. The results of the independent t-test showed that there was an effect of the KB illustration video on the knowledge of family planning acceptors at the Makassar City Health Center $(P=0.012)$. KB illustration video is effective on knowledge of family planning acceptors at the Makassar City Health Center.

Keywords : Baby boom, knowledge, illustration video, pandemic covid-19

https://doi.org/10.33860/jik.v15i3.496 


\section{PENDAHULUAN}

Pelayanan kesehatan salah satunya pelayanan Keluarga Berencana (KB) di fasilitas kesehatan juga terdampak Covid-19, dikhawatirkan bahwa pasangan usia subur atau akseptor KB kemungkinan khawatir untuk datang ke fasilitas kesehatan, di lain pihak fasilitas kesehatan juga kekurangan Alat Pelindung Diri, sehingga timbul risiko putuspakai pemakaian kontrasepsi yang akan berdampak kehamilan tidak direncanakan ${ }^{1}$. Selama wabah pandemi covid-19 peningkatan jumlah bayi yang lahir di tahun 2020 diperkirakan akan ada 116 juta bayi lahir. Selain itu, Indonesia diperkirakan menjadi negara nomor lima dengan jumlah paling banyak bayi lahir. Data dari provinsi menunjukkan cakupan penuh KB pada bulan Januari hingga Maret 2020 rata-rata adalah 2598 akseptor, sedangkan gambaran data $75 \%$ pada April 2020 menunjukkan hanya ada 422 akseptor, terjadi penurunan yang sangat besar.

Strategi penggunaan kontrasepsi alternatif selama masa darurat pandemi Covid19 dapat menggunakan alat kontrasepsi jangka pendek, seperti, pil, suntik, dan kondom, dengan tujuan pasangan usia subur terlindungi oleh KB sehingga dapat mencegah baby boom. Strategi selanjutnya dengan menggerakkan secara aktif pola KIE yang gencar untuk dapat memberikan pemahaman tentang tetap perlunya peyananan $\mathrm{KB}$ dengan menerapkan prosedur pencegahan Covid-19. Juga dengan memberdayakan peran Penyuluh KB/Petugas Lapangan KB untuk berperan aktif dalam penggerakan pelayanan KB pada masa pandemi Covid-19 2,3. Pengembangan metode edukasi menggunakan teknologi perlu dipertimbangkan karena perlunya diminimalkan kontak langsung dengan pasien. Olehnya itu, vidio edukasi berbasis ilustrasi menjadi salah satu metode yang perlu dikembangkan untuk membantu mencegah ledakan penduduk selama pandemi. Salah satu program untuk mengontrol laju pertumbuhan penduduk dan menurunkan angka kematian ibu adalah program Keluarga Berencana (KB). Sasaran program KB diantaranya adalah peningkatan prevalensi pemakaian alat kontrasepsi (Contraseptive Produktif Rate/CPR) menjadi $65 \%$, penurunan PUS tidak mau punya anak, tetapi tidak mau menggunakan kontrasepsi dan peningkatan penggunaan Metode Kontrasepsi Jangka Panjang (MKJP) atau kontrasepsi hormonal menjadi $26,03 \%{ }^{4}$. Penggunaan kontrasepsi menurut usia reproduksi sehat dan muda lebih rendah dibanding kemampuan reproduksi tua, hal ini karena pada kemampuan reproduksi tersebut, WUS masih menginginkan menambah jumlah anak, maka jika pada usia seperti ini tidak dikendalikan, akan menyebabkan ledakan bayi atau baby boom ${ }^{5}$.

Pengambilan keputusan untuk metode kontrasepsi biasanya membutuhkan pertimbangan keuntungan dan kerugian dari berbagai metode yang ada, dan ini bervariasi sesuai keadaan, persepsi, dan interpretasi masingmasing individu. Faktor-faktor ini meliputi karakteristik calon klien, risiko penyakit yang dimiliki, profil efek samping dari berbagai produk, biaya, serta ketersediaan dan preferensi pasien. Dokumen ini tidak memberikan rekomendasi tentang produk atau merek tertentu yang akan digunakan setelah memilih jenis metode kontrasepsi, melainkan memberikan panduan tentang "bagaimana" menggunakan metode kontrasepsi dengan aman dan efektif ${ }^{6,7}$. Keputusan tentang metode apa yang akan digunakan harus mempertimbangkan kelayakan klien untuk menggunakan berbagai metode kontrasepsi. Penggunaan kontrasepsi darurat dapat menjadi alaternatif. Beberapa metode kontrasepsi yang dipakai dalam kondisi darurat ada 2 macam yaitu pil (pil kombinasi: neogynon, eugynon 50, ovral, microgynon 30 , nordette dan pil hanya progestin: postinor-2, microlut) dan AKDR (copper-T). Selain itu, metode kontrasepsi alamiah perlu dipertimbangkan penggunaannya ${ }^{8,9}$.

Menurut hasil penelitian terdahulu, bahwa dilihat dari pendidikan, konseling, dan konselor, sebanyak $60 \%$ responden tidak mengetahui model kontrasepsi yang benar, hanya sedikit wanita berpendidikan lebih tinggi mengetahui metode kontrasepsi yang digunakan ${ }^{10,11}$. Keberhasilan penyuluhan tersebut tidak terlepas dari beberapa faktor yang 
melatarbelakanginya, keberhasilan suatu penyuluhan kesehatan dapat dipengaruhi oleh beberapa faktor penyuluh, sasarn dan proses

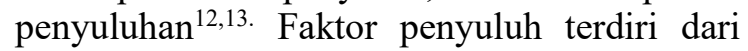
persiapan yang matang, penguasaan materi, penampilan yang meyakinkan, bahasa yang digunakan, penggunaan LCD, penggunaan gambar, penggunaan leaflet. Faktor sasaran yaitu, tingkat pendidikan responden yang ratarata SMA serta suasana yang cukup kondusif. Dengan demikian informasi lebih dapat tersampaikan ${ }^{14,15}$.

Penelitian ini bertujuan untuk mengetahui pengaruh penggunaan vidio ilustrasi family planning terhadap pengetahuan akseptor kb sebagai upaya pencegahan baby boom di masa pandemi covid-19.

\section{METODE PENELITIAN}

Jenis penelitian ini adalah penelitian kuantitatif dengan metode penelitian Quasi Eksperiment dengan pendekatann pretesposttes with control group ${ }^{16}$. Metede ini diawali dengan pengembangan Vidio menggunakan $\mathrm{R}$ \& D untuk menghasilkan vidio yang sesuai kebutuhan masyarakat. Sampel dalam penelitian ini berjumlah 60 orang, kriteria sampel adalah wanita usia subur yang memiliki anak $>2$ dan tidak memiliki riwayat keganasan. Pada penelitian ini terbagi menjadi dua kelompok yaitu intervensi dengan pemberian edukasi dengan vidio ilustrasi dan kontrol menggunakan edukasi konvensional yaitu edukasi tentang macam-macam alat kontrasepsi, manfaat serta efek samping yang diberikan pada akseptor KB dengan menggunakan lembar balik. Tahap selanjutnya di lakukan pengukuran dengan menggunakan kuesioner 5 (lima) menit setelah diberikan intervensi (Vidio Ilustrasi) Analisis data mengunakan SPSS 22 dengan Uji $T$ Independent dan tingkat signifikan $\alpha:<0,05$ maka Ho ditolak dan Ha diterima.

\section{HASIL}

Tabel. 1 menunjukkan bahwa pada vaiabel Pendidikan Ibu mayoritas responden pada kelompok intervensi dan kontrol mayoritas memiliki Pendidikan Tinggi (SMA/S1/S2) yaitu sebanyak 19 orang $(31,7 \%)$ dan 21 orang $(31,5 \%)$. Pada variabel umur mayoritas responden pada kelompok intervensi dan kontrol mayoritas berumur $<35$ tahun sebanyak 22 orang $(36,7 \%)$ dan 23 orang $(38,3 \%)$, Kemudian untuk variabel Pekerjaaan mayoritas responden pada kelompok intervensi dan kontrol tidak bekerja (IRT) sebanyak 29 orang $(48,3 \%)$ dan 27 orang $(45 \%)$.

Tabel 1. Distribusi Frekuensi Karakteristik Responden

\begin{tabular}{|c|c|c|c|c|c|c|}
\hline \multirow{3}{*}{ Karakteristik } & \multicolumn{4}{|c|}{ Kelompok } & \multirow{2}{*}{\multicolumn{2}{|c|}{ Total }} \\
\hline & \multicolumn{2}{|c|}{$\begin{array}{c}\text { Edukasi dengan } \\
\text { Video Ilustrasi KB }\end{array}$} & \multicolumn{2}{|c|}{$\begin{array}{c}\text { Edukasi } \\
\text { konvensional }\end{array}$} & & \\
\hline & $\mathrm{n}$ & $\%$ & $\mathbf{n}$ & $\%$ & $\mathbf{N}$ & $\%$ \\
\hline \multicolumn{7}{|l|}{ Pendidikan } \\
\hline Tinggi & 19 & $31.7 \%$ & 21 & $31.5 \%$ & 40 & $66.7 \%$ \\
\hline Rendah & 11 & $18.3 \%$ & 9 & $15 \%$ & 20 & $33,30 \%$ \\
\hline \multicolumn{7}{|l|}{ Umur } \\
\hline$\leq 35$ tahun & 22 & $36.7 \%$ & 23 & $38.3 \%$ & 45 & $75 \%$ \\
\hline$>35$ tahun & 8 & $13.3 \%$ & 7 & $11.7 \%$ & 15 & $25 \%$ \\
\hline \multicolumn{7}{|l|}{ Pekerjaan } \\
\hline Bekerja & 1 & $1.7 \%$ & 3 & $5 \%$ & 4 & $6.7 \%$ \\
\hline Tidak Bekerja & 29 & $48.3 \%$ & 27 & $45 \%$ & 56 & $93,30 \%$ \\
\hline
\end{tabular}


Tabel 2. Efektivitas Pemberian Vidio Ilustrasi Family Planning Terhadap Pengetahuan Akseptor KB di Puskesmas Wilayah Kota Makassar Tahun 2021

\begin{tabular}{lllcc}
\hline & Kelompok & N & Rata-rata \pm SD & Nilai P \\
\hline \multirow{2}{*}{ Pengetahuan } & Intervensi & 30 & $58,89 \pm 15,86$ & 0,012 \\
\cline { 2 - 4 } & Kontrol & 30 & $45,47 \pm 4,31$ & \\
\hline
\end{tabular}

\section{PEMBAHASAN}

Berdasarkan hasil penelitian menunjukkan bahwa dari 60 responden yang dteliti didapatkan hasil uji t independent dengan nilai $P$ Value $0,012 \quad(<0,05)$ sehingga menunjukkan ada pengaruh penggunaan video ilustrasi family planning terhadap pengetahuan akseptor KB di Puskesmas Wilayah Kota Makassar $(P=0,012)$. Nilai rata-rata pengetahuam Akseptor KB yang diberikan edukasi vidio ilustrasi family planning yaitu 58 , $89 \pm 15,86$, dimana nilai tesebut lebih tinggi dibandingkan dengan nilai rata-rata pengetahuan pada kelompok yang diberikan edukasi konvensional (Lembar timbal Balik)

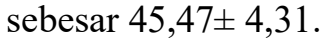

Vidio merupakan suatu media yang menarik bagi masyarakat terutama jika digunakan dalam edukasi. Antusias masyarakat juga meningkat pada pemberian edukasi berbasis video. Video edukasi kesehatan adalah alat praktis dan ekonomis yang dapat digunakan untuk mempromosikan kesehatan dimasa pandemic Covid-19. Video edukasi merupakan rekaman gambar hidup yang ditayangkan beserta isi pesan serta moral terhadap individu, kelompok, ataupun masyarakat ${ }^{11}$. Video edukasi juga dapat digunakan sebagai sarana penyampaian informasi dimanapun dan kapanpun sedangkan lembar timbal balik penyampaian dan waktu penyampaiannya terbatas.

Pengetahuan merupakan hasil dari tahu, dan ini terjadi setelah orang melakukan penginderaan terhadap suatu objek tertentu. Tingkat pengetahuan ibu tentang metode kontrasepsi yang diperoleh dari pemberian informasi yang akurat ikut berperan dalam keputusan ibu untuk memilih dan menggunakan metode kontrasepsi ${ }^{12}$.

Pengetahuan akseptor pada kelompok perlakuan lebih meningkat dibandingkan dengan kelompok kontrol. Hal ini dikarenakan Video edukasi berisikan berbagai aspek seperti gambar, animasi, suara dan teks. Media video juga menyediakan pesan audiovisual yang mengikutsertakan indra penglihatan dan pendengaran sehingga memungkinkan responden dapat menyerap lebih banyak dari materi yang diberikan. Sedangkan edukasi konvensional (menggunakan lembar timbale balik) hanya berisikan gambar dan teks ${ }^{11}$. Proses pendidikan kesehatan dengan melibatkan lebih banyak indera akan lebih mudah diterima dan diingat oleh sasaran pendidikan ${ }^{15}$.

Hasil penelitian ini sejalan dengan hasil penelitian yang dilakukan oleh Febriani (2019) yang menunjukkan bahwa pengetahuan ibu akseptor KB yang diberikan edukasi berbasis video meningkat pada kemampuan kognitif dimana hasil posttest didapatkan bahwa semua akseptor $\mathrm{KB}$ berpengetahuan cukup tahu sehingga ada perubahan peengetahuan setelah diberikan media berbasis video.

Hasil penelitian ini sejalan dengan hasil penelitian yang dilakukan oleh Marizi (2019) yang menjelaskan bahwa media audiovisual tentang IUD efektif terhadap peningkatan pengetahuan wanita usia subur di Puskesmas Sematang. Responden yang berpengetahuan Baik sebelum intervensi sebanyak 4 responden $(13,3 \%)$, Cukup sebanyak 15 responden dan kurang sebanyak 11 responden $(36,7 \%)$. sedangkan sesudah intervensi yang bepengetahuan baik sebanyak 21 responden (70\%), cukup sebanyak 8 responden $(26,7 \%)$ dan kurang sebanyak 1 responden $(3,3 \%)^{14}$.

Penyuluhan kesehatan sangat penting bagi Wanita Usia Subur (WUS) dalam memilih alat kontrasepsi. Penyuluhan dengan metode yang menarik dan efektif sangat berpengaruh dalam menentukan keberhasilan promosi keluarga berencana sehingga diharapkan 
kejadian baby boom dimasa pandemi ini dapat dicegah. Edukasi dengan menggunakan Video Ilustrasi KB merupakan salah satu cara yang dapat berkontribusi dalam keberhasilan promosi keluarga berencana.

Berdasarkan asumsi peneliti bahwa peningkatan suatu pengetahuan dapat diberikan dengan cara melalui media berbasis video secara signifikan. Kemudian dari hasil observasi dan wawancara terhadap beberapa responden diketahui bahwa pendidikan, pengalaman, status ekonomi serta kepercayaan/budaya yang masih begitu kental dan melekat di masyarakat yang menyebabkan beberapa responden takut serta berfikir kembali untuk memakai alat kontrasepsi sehingga perlu diberikan pengetahuan melalui video.

\section{KESIMPULAN DAN SARAN}

Vidio Ilustrasi Family Planning efektif terhadap peningkatan pengetahuan akseptor $\mathrm{KB}$ karena salah satu cara meningkatkan suatu pengetahuan yaitu melalui media berbasis video yang penyajiannya unik, kreatf, dan inovatif serta dapat diberikan melalui online sehingga peneliti tidak perlu bersentuhan langsung dengan responden.

Diharapkan kepada akseptor atau calon aksepor agar lebih aktif dalam mecari informasi terkait alatn kontrasepsi dalam upaya meningkatkan pemahamannya sebelum mengambil keputusan, dan petugas kesehatan khususnya bidan dapat menerapkan media berbasis video pada penyuluhan pasangan usia subur yang ingin menggunakan alat kontrasepsi hormonal maupun non hormonal.

\section{UCAPAN TERIMA KASIH}

Ucapan terima kasih ditujukan kepada institusi DRPM Ristekdikti selaku penyandang dana penelitian, LPPM Universitas Megarezky yang telah menfasilitasi tim peneliti, Instansi tempat penelitian serta responden yang telah bersedia mengikuti penelitian ini.

\section{DAFTAR PUSTAKA}

1. Starbird E, Norton M, Marcus R. Investing in family planning: Key to achieving the sustainable development goals. Global Health
Science and Practice. 2016;4(2):191-210.

2. Stanback J, Steiner M, Dorflinger L, Solo J, Cates W. WHO tiered-effectiveness counseling is rights-based family planning. Global Health Science and Practice. 2015;3(3):352-7.

3. Spindler E, Bitar N, Solo J, Menstell E, Shattuck D. Jordan's 2002 to 2012 fertility stall and parallel USAID investments in family planning: Lessons from an assessment to guide future programming. Global Health Science and Practice. 2017;5(4):617-29.

4. Kartikawati D, Pujiastuti W, Rofiah S. Efektivitas pendidikan kesehatan dengan media video untuk meningkatkan sikap dan niat penggunaan AKDR. Midwifery Care Journal. 2020;3(1):1-11.

5. You D, Hug L, Anthony D. UNICEF report Generation 2030 Africa calls upon investing in and empowering girls and young women. Reproductive Health. 2015;12(1):10-3.

6. Ngangun AF, Sumi SS, Simunati. Pengaruh Media Berbasis Video Terhadap Pengetahuan Ibu Puskesmas Pattingalloang. Jurnal Ilmiah Kesehatan. 2019;14:313-7.

7. Marizi L, Novita N, Setiawati D. Efektivitas Media Audiovisual Tentang Kontrasepsi Intra Uterine Device Terhadap Pengetahuan Wanita Usia Subur. JPP (Jurnal Kesehatan Poltekkes Palembang). 2019;14(1):7-12.

8. Young Hee Choi and A-MY. 乳鼠心肌提取 HHS Public Access. Physiology \& behavior. 2019;176(3):139-48.

9. Herowati D, Sugiharto M. Hubungan Antara Kemampuan Reproduksi, Kepemilikan Anak, Tempat Tinggal, Pendidikan Dan Status Bekerja Pada Wanita Sudah Menikah Dengan Pemakaian Kontrasepsi Hormonal Di Indonesia Tahun 2017. Buletin Penelitian Sistem Kesehatan. 2019;22(2):91-8.

10. Tessema GA, Gomersall JS, Mahmood MA, Laurence CO. Factors determining quality of care in family planning services in Africa: A systematic review of mixed evidence. PLoS ONE. 2016;11(11):1-23.

11. Rusatira JC, Silberg C, Mickler A, Salmeron C, Twahirwa Rwema JO, Johnstone M, et al. Family planning science and practice lessons from the 2018 International Conference on Family Planning. Gates Open Research. $2020 ; 4$.

12. Fitriana N, Rosyidah I. Pengembangan penyuluhan kesehatan meningkatkan 
pemakaian alat kontrasepsi di puskesmas Purwoyoso kota Semarang. Jurnal Riset Kebidanan Indonesia. 2021;4(2):77-83.

13. Nagari PM, Savitri OI, Putra AH, Anggraeni DS, Surya Nugraha AA. Edukasi Kesehatan Melalui Video Sebagai Upaya Antisipasi Covid-19 Di Desa Pandansari Lor. Jurnal Pengabdian dan Peningkatan Mutu Masyarakat (JANAYU). 2021;2(1):60-5.

14. Pfitzer A, Lathrop E, Bodenheimer A, RamaRao S, Christofield M, MacDonald P, et al. Opportunities and challenges of delivering postabortion care and postpartum family planning during the covid-19 pandemic. Global Health Science and Practice. 2020;8(3):335-43.

15. Juma PA, Mutombo N, Mukiira C. Women's attitudes towards receiving family planning services from community health workers in rural Western Kenya. African Health Sciences. 2015;15(1):161-70.

16. Sugiyono. Metode Penelitian Kombinasi (Mix Methods). 2015. Bandung: Penerbit: Alfabeta 